\title{
ESKİ TÜRKÇE bögü/bügü ve bokuk/bokug/bukuk/bukug SÖZCÜKLERINIIN KULLANIM VE ANLAMLARI HAKKINDA
}

\author{
ON THE USAGES AND MEANINGS OF OLD TURKIC WORDS \\ bögü/bügü AND bokuk/bokug/bukuk/bukug
}

Münevver Ebru ZEREN*

\begin{abstract}
$\ddot{O} z$
Eski Türkçede özel kişi adı veya unvan olarak da karşımıza çıkan bögü/bügü sözcüğünün kökeni, anlamı ve etimolojisi hakkında şimdiye kadar farklı görüşler ortaya konmuştur. bögü/bügü, Hun, Göktürk ve Uygur dönemlerinde kullanılmış olan bokuk/bokug/bukuk/bukug sözcü̈̆̈̈ ile de ilişkilendirilmiştir. Bu konuyu tekrar gündeme getirme sebebimiz ise, son araştırmalarda Uygur yazıtlar ve metinlerinde bokuk sözcü̈̆̈̈̈nden bir boy adı olarak bahsedilmesinin yanı sıra bögü kelimesinin dini anlamı hakkında yapılan yeni önerilerin, eski bilgilerle birlikte yeniden değgerlendirilmesinin katkı sağlayabileceğgi düşüncesidir.

Makalemizde öncelikle geçmiş çalışmalar ışığında bu sözcüklerin geçtiği bazı önemli metinleri inceledik ve son zamanlarda ortaya atılan bazı görüşleri tanıttık. Ardından Türk kültür tarihinde bu sözcüklerin hangi bağlamda, hangi anlamı ifade etmek üzere kullanıldığ birbiriyle ilişkileri hakkında görüşümüzü ortaya koymaya çalıştık. Son olarak bögü/bügü'nün kökeni ve en eski anlamının ne olabileceği hususunda önerilerde bulunup henüz açık ve araştırılması gereken noktaların altını çizdik..
\end{abstract}

\section{Anahtar Kelimeler}

Bögü, bügü, Bokuk, Bukug, etimoloji, semantik, antroponim, Eski Türkçe.

\begin{abstract}
Different opinions have been put forward so far on the root, meaning and etymology of the Old Turkic bögü/bügü word that came out as a personal name or title. bögü/bügü has also been associated with the word bokuk/bokug/bukuk/bukug used in Hun, Gokturk and Uyghur periods. The reason for bringing this matter back to the agenda is that recent researches on Uighur inscriptions and texts where bokuk is referred to as a clan name, as well as the re-evaluation of the new suggestions about the religious meaning of bögü together with the old information.

In our paper we first examined the usage of these words within some important texts in the light of past studies and introduced some of the ideas that have recently emerged. Then, we tried to express our opinion about the contexts and meanings of them, and how these uses relate to each other in Turkish cultural history. Finally, we made suggestions about what might be the root and the oldest meaning of bögü/bügü, and underlined the points that need to be clarified and investigated yet.
\end{abstract}

\section{Keywords}

Bögü, bügü, Bokuk, Bukug, etymology, semantics, antroponym, Old Turkic.

\footnotetext{
* Dr. Öğr. Üyesi, Haliç Üniversitesi Fen-Edebiyat Fakültesi Tarih Bölümü, ebruzeren@yahoo.com
} 


\section{Giriş}

Eski Türkçede özel kişi adı veya unvan olarak da karşımıza çıkan destan bögü/bügü sözcüğünün kökeni, anlamı ve etimolojisi hakkında şimdiye kadar farklı görüşler ortaya konmuştur. bögü/bügü, Hun, Göktürk ve Uygur dönemlerinde kullanılmış olan bokuk/bokug/bukuk/bukug sözcüğü ile de ilişkilendirilmiştir. Bu konuyu tekrar gündeme getirme sebebimiz ise, son araştırmalarda Uygur yazıtları ve metinlerinde bokuk sözcügüunden bir boy adı olarak bahsedilmesinin yanı sıra bögü kelimesinin dini anlamı hakkında yapılan yeni önerilerin, eski bilgilerle birlikte yeniden değerlendirilmesinin katkı sağlayabileceği düşüncesidir.

Çin kaynakları, Türk yazıtları, Uygur Maniheist ve Budist metinleri, Uygur destanları ve Kutadgu Bilig'de geçen bögü/bügü sözcüğünün Türkçede başlıca "bilgin, akıllı, bilge, hakim, âlim, kutsal, hekim, büyücü" anlamlarına geldiği geçmiş çalışmalarda belirtilmiştir ${ }^{1}$. Çin tarihi kaynaklarında Çince transkripsiyonu ile; Uygur metinleri ve sikkeleri üzerinde ise Uygur yazısı ile karşımıza çıkan bügü/bogug/bugug/bokuk/bokug/bukuk/buku gibi sözcüklerin de bögü'nün eşdeğeri olduğu, başta A. von Le Coq olmak üzere bazı uzmanlar tarafından öne sürülmüştür. Bügü/bokuk sözcüklerinin eşdeğerliği görüşü de, öncelikle E. Chavannes ve P. Pelliot tarafından reddedilmiş ve Orhun dönemi Uygur sikkelerini inceleyen F. Thierry tarafından da iki kelimenin farklı olduğu epigrafik buluntulara dayanarak detaylı olarak açıklanmıştır (Thierry 1998). Gerek Uygur Türkçesindeki yazılışları, gerekse aşağıda bahsedeceğimiz Turfan Uygur İdikut kitabesinden boquq'un Çince yazılışının bügü'nünkinden farklı olması sebebiyle bu tartışmanın sona erdiğini söylemek mümkündür. Ancak bu iki kelimenin arasında dilbilim ve semantik açıdan ilişki olup olmadığı da tartışmalıdır.

Eski Türkçe sözvarlığının en büyük etimoloji uzmanlarından G. Clauson etimoloji sözlüğünde bögü veya bögö’nün "bilge, büyücü" anlamına geldiğini ve bu sözcüğün hem hikmet, hem de mistik ruhanî gücü ifade etmekte kullanıldığını kaydetmiştir (Clauson 1972: 324). Eski Türkçe metin örnekleri de bize söz konusu sözcügün akıl ve hikmet ile yakından bağlantılı olduğunu göstermektedir. Ancak bögü, çoğunlukla bilge ile aynı anlamda ve "bükü bilge" (Kaşgarlı Mahmud 1941: 228) şeklinde ikileme şeklinde kullanılmakla birlikte bögü sözcüğünün sadece "ilim" değil, "irfan sahibi" ve sadece akla dayanan hikmet dişında "ruhani bir güç ve erdemle donanmış olma"yı ifade ettiğini söylemek de mümkündür. Aşağıda sözkonusu sözcügüü Eski Türkçenin farklı dönemlerinde farklı anlamlarda ve şekillerde kullanımına ilişkin belli başlı örnekler sunulmuştur.

\section{Hun Döneminde bokuk/bokug/bukuk/bukug}

Hun dönemine ait yazılı kaynaklarda bögü sözcüğüne rastladığımız bir metin örneği bulunmamıştır. Ancak, Türklerin bilinen en eski metni olarak kabul edilen Chin-Shu Yıllığındaki IV. yüzyıldan kalan ve L. Bazin tarafından Çince'den çevrilerek yorumlanan bir Hun beyitinde2 "bokug/bukuk" unvan şeklinde geçmektedir.

1 Bu sözcük bahsedilen eserlerde bögü, bögö, bügü, bükü gibi farklı telaffuzları ile birlikte yer almış; nitekim dizinde bu sözcüklerden biri açıklanırken diğerleri bu sözcüğe atıfta bulunmuşlardır: (Kaşgarlı Mahmud 1941:228), (Arat 1979: 119), (Caferoğlu 1993: 33), (Clauson 1972: 324), (LeCoq 1912:149), (LeCoq 1913:541,543), (Bang, Gabain 1929: 412-413), (Chavannes, Pelliot 1911: 212, 221), (Hamilton 1986, VIII, XVII), (100. Doğum Y1l Dönümüne Armağan C.I 2008: 179), (Bang, Gabain 1931:18), (Gabain 2007: s. 271).

2 Louis Bazin, “Un Texte Proto-Turc du IVe Siècle: Le Distique Hiong-nou du "Tsin-Chou”, Oriens, Vol.1, No. 2, 1948, s. 3-11. Aynı makale Bazin'in bazı önemli makalelerinin derlendiği ve bizim de referans olarak kullandığımız 


\section{1) Özel Kişi Adlarında Unvan olarak kullanılan bokug/bukuk}

Yukarıda bahsedilen beyit, Chin-Shu Yıllığında yer alan M.S. IV. yüzyılın başında Hindistan'dan Şansi'ye gelen Budist Rahip Fo-t'u-teng'in biyografisinde, rahibin aynı sene (329) Sonraki Chao Hanedanı'nı kuracak olan Kuzeydoğu Çin'in Hun hükümdarı Shih-Lo'ya Hun dilinde söylediği bir kehaneti aktarmaktadır. Bahsedilen tarihte başka bir Hun reisi olan Liu Yao Loyang şehrini kuşatıyor; Shih Lo ise ona karşı koymak istiyor, ancak maiyeti onu vazgeçirmeye çalışıyordu. Hükümdarın rahibe danışmasıyla rahibin söylediği Çince transkripsiyonlu Türkçe kehanet metni ve Bazin tarafından yapılan tercümesi şu şekildedir:

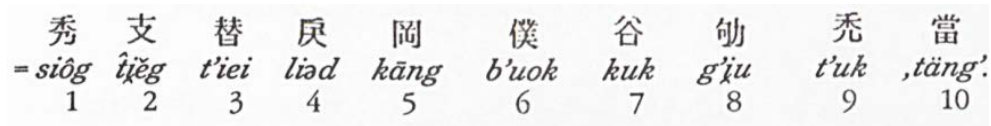

“Çanın sesi şöyle söylüyor: Ĕ̆ger ordu çıkarsa Liu Yao yakalanacak” (Bazin 1994: 3-4)

Bazin, bu metinde 6.-7. karakterlere karşı gelen sözcüğü b'uok-kuk olarak okumuş ve bunun muhtemelen Liu Yao'nun Hun unvanını belirttiğini Türkçe yazıtlar ve Osmanlıca "askeri komutan, bir bölüğün başı" anlamına gelen bor sözcüğü ile karşılaştırmak suretiyle ileri sürmüştür. Bazin'in açıklamalarından görüldüğü üzere; bokug sözcüğü özellikle kişi unvanlarında kullanıldığında "askerî komutan" anlamına gelmekte ve sonraki dönemde "buğ" sözcüğü olarak karşımıza çıkmaktadır.

\section{2) Boy ve hayvan adı olarak bokug/bukuk ve türevleri}

Makalesinin sonunda Bazin, W. Eberhard'ın bokug sözcüğüne fonetik olarak çok yakın olan diğer Çince transkripsiyonları ile ilgili görüşlerini de ileterek sözcüğün anlamına ilişkin daha ilginç çıkarımlar ve bazı soruları ortaya koymaktadır (Bazin 1994: 11). Bahsedilen transkripsiyonlar, Hsin Tang-shu'da adı geçen ve buku Kırgız Türkçesi ve Moğolca'da "geyik" anlamına geldiği için ${ }^{3}$ bu hayvanla ilişkisi olduğunu düşündüğü bir Töles boyu (uruğu?) olan $b^{\prime} u o k-k u o$ veya b'uok-kuet ve bunun lideri $P^{\prime} u-k u$ Huai-en; yine Töles ile ilgili olarak veya XII. yüzyılda görülen Kadir Buku Han örneğinde olduğu buku sözcüğünün unvan olarak yer aldığı, Chiu-wu-tai-shih $25^{\prime}$ de adı geçen ve Türkçe Tołra Buku olarak okunması gereken X. yüzyıl Şatolar'ı ile ilgili özel kişi adı d'ung-lā-b'uok-kuet ve Chavannes'ın Batı Türkleri ile ilgili eserinde adı geçen; Minorsky tarafından Hududü'l-Alem'de Kara İrtiş Nehri ile ilişkilendirilen ve Türkçe bukuçın olarak okunması gereken $b^{\prime} u o k-k u o^{\prime}-t^{\prime}$ siĕn' $^{\prime}$ dir

\section{Göktürk Döneminde bögü/bükü ve bokuk/bokug/bukuk/buku}

Göktürk ve Uygur dönemi yazıtlarındaki söz varlığını inceleyen $H$. Şirin'in eseri, bize bögü ve bukug sözcüklerinin nasıl kullanıldığı konusunda önemli bilgiler sunmaktadır. Ayrıca E. Aydın, incelediği Yenisey yazıtlarından üçünde bögü sözcüğünü kağanın unvanı olarak tespit etmiştir (Aydın 2011: 12).

Bögü/bög< $\ddot{u}>$ sözcüğü kağana ilişkin bir unvan niteleyicisi olarak bög< $\ddot{u}>\mathrm{k}(\mathrm{a}) \mathrm{g}(\mathrm{a}) \mathrm{n}$ şeklinde Tonyukuk Yazıtı 34. ve 49.-50. satırlarında yer almaktadır (Şirin User 2010: 274). 49.-50.

kitapta da yayınlanmıştır: (Bazin 1994: 3-11). Bu makalenin tümünün tercümesi, daha sonra yazar tarafından yayımlanacaktır.

3 I. Göktürk Devleti dönemine ait Bugut Yazıtı'na adını veren "bugut" sözcügü̈ de Eski Türkçe "geyik" anlamına gelen "buku/buğu” sözcüğünün /+t/ çokluk eki almış hali olup "geyikler" anlamına gelmektedir (Alyılmaz 2003: 12, dipnot 1). 
satırlarda ard arda yazılmış ilteri̧̧ kaganka:türk bögü kaganka:türk bilge kaganka sözleri yer almaktadır. Bahsedilen kağanın Çince kaynaklarda adı Mochuo 默啜 olarak geçen, İlteriş Kağan'ın kardeşi Bögü Çor Şad olduğu ve tahta geçince de Türk Bögü Kağan adını alan Kapağan/Kapğan Kağan olduğu tespit edilmiştir. (Sertkaya 1995: 81; Aydın 2011: 12).

Bukug sözcüğü ise diğer bir unvan niteleyicisi olarak Bilge Kağan Yazıtı (G 10-11)'nda Bilge Kağan'ın cenazesine katılan ve etnik mensubiyeti bilinmeyen bukug tutuk şeklinde geçmektedir (Şirin User 2010: 257).

\section{Orhun ve Turfan Uygurları Döneminde bögü/bükü ve bokuk/bokug/bukuk/bukug}

\section{1) Özel Kişi Adlarında Unvan olarak kullanılan Bögü ve Bokug/Bukuk/Bokuk}

Bu şahıslar arasında en çok bilineni şüphesiz Orhun Uygurları' nın Maniheizm'i devlet dini olarak kabul eden ünlü kağanı Bögü Kağan (759-779)'dır. Çin kaynaklarında I-ti-chien / Mou-yü olarak adı geçen kağanın bu adlara tekabülen sırasıyla "kutsal" anlamında Bögü Kă̆an ve Tengri Kağan adlarını kullandığı bilinmektedir (Weicuyi : 213, Klimkeit : 365). Ayrıca bir çok Çin kaynağında yer alan ve Cüveynî tarafından nakledilen Uygurlar'ın Türeyiş Destanı'nda adı geçen ağacın büyüyen budağına ve ağaçtan doğan beş çocuktan en iyisi olana Çin kaynaklarında Boguk Han, Cüveynî’de ise Boku/Buku Tegin dendiği bilinmektedir (Clark 2009: 62). J.-P. Roux, destanda adı geçen Buku Kağan'ın, Maniheizm'i kabul eden Bögü Kağan değil, aynı unvana sahip Orhun Uygurları döneminde Maniheizm' in altın dönemini yaşatan, 795-805 yılları arasında hüküm süren Ediz boyunun mensubu Alp Bilge Kağan olduğunu düşünmektedir (Roux 2015: 60-61). Uygur tarihinde bögü veya bokug'un birden fazla kağanın adı veya unvanı olarak kullanılması hasebiyle bu kağanın Çince hangi kağana denk geldiği de özellikle nümizmatik uzmanları için de tartışma konusu olmuştur. F. Thierry de A. Takeo, J. Hamilton ve T. Moriyasu'nun belirttiği gibi; incelediği 795-808 yıllarına tarihlenen sikkelerde adı geçen Bokuk Han'ın (Boquq Khan) Bögü Kağan ile aynı kişi olmadığı ve Çince kaynaklarda Huaixin Kagan olarak geçen Ediz uruğunun ilk kurucu hanedanı kağan olduğunu bildirmiştir (Thierry 1998 : 270).

Bukug sözcü̆ğü bir unvan niteleyicisi olarak Taryat Yazıtında (B-8) da yer almaktadır (Şirin User 2010: 257).

\section{2) Boy Adı olarak bokug/bokuk/buku}

Uygur Türeyiş Destanı dışında üç Uygur metninde daha bokug veya bokuk sözcüğünün geçtiğini ifade eden L. Clark, Türkçe bokug sözcüğünün etimolojisini araştırdıktan ve bunun "kuş kursağı, budak, yumru" anlamlarına geldiğini belirtmiş ve incelemelerinin sonunda bunun bir hükümdara değil, bir boya işaret ettiği fikrini ortaya atmıştır. Bu nedenle ona göre Berlin Turfan Koleksiyonundaki U I no'lu metinde yer alan Uygur Bokug Han, “Bokug boyunun Uygur hanı" olarak okunmalıdır (Clark 2009: 66). Clark, Bokug ile Dokuz Oğuzlar'ın ikincisi olarak sayılan $P^{\prime} u-k u$ (Buku) arasındaki benzerliğe ve Tarım'a göç eden Uygurlar'ın liderlerinin isminin P'ou-kou-tsiun olmasına dayanarak hâlâ karmaşık bir konu olarak görülen Uygur etnonimi ile ilgili yeni bir yaklaşım ortaya koymaktadır: Çin kaynaklarında Dokuz Oğuzlar'ın listesinde ilk sırayı alsa da, Uygur bir boy olmayıp, ikinci sıradaki Bokug boyunu oluşturan uruglar topluluğunu (On Uygur) ifade etmektedir (Clark 2009: 66-67). 
Kelimenin benzer bağlamda kullanımını içeren ikinci bir örnek, geç Uygur metinlerinden biri olan ve 1933 yılında Kansu eyaletinin Wou-wei (Leang-tcheou) şehrinin kuzeyinde bulunmuş Uygur Türkçesi ve Çince olmak üzere iki dilli yazılmış Turfan İdikutları hakkındaki yazıtta yer almaktadır (Shimin, Hamilton 1981: 11) ${ }^{4}$. 1275-1334 yılları arasında yaşayan Koço İdikutları'nın yaptıklarını öven bu yazıtın alt kısmının Temür Buka'nın babası olan Nieou-lin Tigin (Nolin Tekin /Ne'uril Tekin) 'in 1318'de öldügüü Yong-tch'ang yakınında yer alan Wouwei'de bulunması, burada onun mezarının yer aldığını düşündürmektedir (Shimin, Hamilton 1981: 12-13). Yazıtın Türkçe metninde Barçuk Art Tigin, Mamurak Tigin, Öng Tigin Begi, Koçgar Tigin, Senggi Tigin, Babaça Aga, Turçisman Aga ve Temür Buka Tigin gibi bir çok hükümdar ailesi üyelerinin ismi ve onlar hakkında bilgi yer almaktadır. Begi veya beki unvanı ise idikutun kızı için kullanılmıştır (Shimin, Hamilton 1981: 33-34). Öng Tigin Begi için yazıtta yer alan bokuk tözlüg pundarik çeçek ifadesi Shimin ve Hamilton tarafından "bokuk kütü̈̆̈̈nün -soyunun- lotus çiçeği" (bokuk tözlüg pundarik çeçek) olarak tanımlanmıştır. Bu tercüme ile araştırmacılar bokuk sözcüğünün "ağaçtaki budak, yumru" anlamına olduğu gibi Bokug soyuna da atıfta bulunmuş görünmektedirler. Ancak bokuk tözlüg ifadesi ile nitelenen lotus çiçeğinin Budizm'de saflı̆̆ı ve kutsallı̆̆ simgelemesi sebebiyle Budist Turfan Uygurları için bu ifade "kutsal" anlamına da geliyor olabilir.

\section{3) Erdem belirten nitelik belirteci olarak bögü/bügü}

Eski Türkçe Budist metinlerde bögü/bügü sözcüğü genellikle Budizm'de önemli yer tutan "bilgelik, hikmet" (Sanskrtiçe prajūā) kavramını karşılamak üzere kullanılmıştır. Mahayana Budizmi'nde önemli yer tutan ve bu kavramı açıklayan bir çok sutraların yazıldığı prajñāpāramitā da bir erdem olarak üstün bilgi, hikmet, ilahi bilgi ve irfan anlamlarına gelmektedir (Yılmaz 2007: 208). prajñā sözcüğünün sadece akıl ile ulaşılan bilgelik değil, mistik, ruhani veya ilahi yolla edinilecek sezgi, idrak ve kavrayış ifade eden irfan sözcüğü ile karşılanması bögü/bügü'nün ilahi, mistik anlamını kavramak açısından önemlidir.

Bögü/bügü sözcügüunün ve türevlerinin "bilgelik, hikmet, tefekkür, erdem" gibi özellikle aklın işlevinin ön plana çıktığı sıfat ve adlarda kullanımı, Eski Budist Uygur metinlerinde ikilemeler şeklinde çıkmaktadır : bügü biliglig (hikmetli), bügülüg edremlig (erdemli), bügün- sakın(tefekkür edip düşünmek), bügüş sakınç (anlayış, düşünüş) (Şen 2002: 81), çınkar-bügün-bil- (düşünüp anlamak) (Şen 2002: 87), sakın-bügün (düşünmek) (Şen 2002: 237), sakınç bügüş (düşünce, tefekkür) (Şen 2002: 238).

Bögü/bügü sözcügü ile yukarıda adı geçen bügüş (isim), bügün- (fiil) gibi türevlerine de; ekleşme açısından Eski Uygur Türkçe Grameri'ni örnekleriyle ele alan değerli Türk dili uzmanlarının öne sürdüğü görüşler doğrultusunda kısaca değinmek gerekir. S. Şen'e göre bögü kelimesinin kendisi, bög- "anlamak" fiilinden +ü yapım eki ile türetilmiştir (Şen 2015:182). Dolayısıyla bügüş kelimesi de "anlayış" olarak günümüz Türkçesinde ifade edilebilir. Tokyürek, bügüş kelimesini sakınç kelimesi ile eşdeğer olarak "düşünce" olarak günümüz Türkçesine çevirmiştir (Tokyürek 2011: 35, 36). A. von Gabain ve K. Eraslan'a göre bügüş, bügü'den isimden isim yapan ve örneğine az rastlanan bir yapım eki olan $+s ̧$ kullanılarak türetilmiştir ve "dirayet" (Gabain 2007: 45) veya "hikmet" (Eraslan 2012: 102) anlamında

4 İlk olarak Yuan döneminde yayınlanan bu yazıtın Çince metni 1964 yılında Houang Wen-pi tarafından Wen-wou adlı eserde yayınlanmıştır. Fransızca metni ise ilk olarak verilen makalede G. Shimin ve J. Hamilton yayınlamışlardır. 
kullanılmıştır. Eraslan, bu kelimenin Sanskritçe prajñā kelimesinin tam karşılığı olduğunu belirtir.

Bügün- fiili ise; daha ziyade "yapmak" ifade eden ve dönüşlülük şeklinden meydana geldiği düşünülen; isimden fiil yapma $+n$ eki kullanılarak türetilmiştir (Eraslan 2012: 115). Gabain, bügün- fiilini "vakıf olmak, tanımak" olarak tanımlamıştır (Gabain 2007:271). Tokyürek de tezinde fiili aynı anlamı ifade edecek şekilde açıklamıştır (Tokyürek 2011: 432). M. Erdal'a göre "toplamak, birleştirmek" anlamındaki bög sözcüğünden türetilen bögünmek fiili ise “anlamak, kavramak, farkına varmak" anlamını taşımaktadır (Erdal 1991: 595).

R. R. Arat, bügü sözcüğünden türetilen bügülemek sözcüğünün anlamını "bilgi ile techiz olmak" olarak vermiştir (Arat 1979:119). Erdal ise bügülenmek dönüşümlü fiilini "mistik hikmete sahip olmak" olarak tercüme etmiştir (Erdal 1991: 597). Mahayana Budizminde Bodisatvaların Buda olmaları için gereken altı erdem (Skr. pāramitā), Eski Türkçede altı paramıt olarak kullanıldığ1 gibi altı törlüg bügülenmek erdem olarak da geçmektedir (Tokyürek 2011, 239). Tokyürek bügülenmek sözcüğünü "bilgelik" olarak günümüz Türkçesine çevirmiştir. Eraslan da bügülenmek fiilini, muhtemelen Budalığın üstün erdemlerine erişmek anlamında "olağanüstü olmak" olarak açılamıştır (Eraslan 2012:563) Kanaatimizce Eraslan'ın bu açıklaması, bügü kelimesinin sonraki "büyü" anlamlarında kullanılışının kaynağına 1şık tutmaktadır; zira bir kişi Buda olmakla fiziki ve ruhi anlamda üstün varlık konumuna yükselmiş olmakta ve bir çok mucizeler gösterebilmektedir.

Bögü'nün "doğru" anlamında kullanımı da Uygur metinlerinde karşımıza çıkmaktadır. Örneğin Maitrisimit'in Hami versiyonunda "oñalı bögüş urmak (doğru düşünce düşünmek)" (Tokyürek 2011: 46) ifadesi geçmektedir. Aynı metinde geçen bögü biliglig burkanlar ifadesi (Tokyürek 2011: 152) bilge anlamında ikileme anlamında kullanılmış olabileceği gibi "doğru bilgi, hikmet" sahibi olarak da yorumlanabilir. Yine bilinen en eski şairimiz Şingko Seli Tutung'un "Köni ögeli bügüş urgıl odugın sakın" ifadesi de Arat tarafından "Doğru muhakeme etmek için hikmet kullan, uyanık ol" olarak tercüme edilmiştir (Arat 2007 : 120-121)5. Bögü'nün bu erdemlilik belirten vasıfları, "dirayetli, güçlü, kuvvetli" anlamlarını da içerecek şekilde değişime uğramış görünmektedir. Nitekim Türk lehçeleri ve Moğolca'da "kuvvetli, pehlivan" anlamlarında kullanılan böke sözcüğünün bögü'den türetildiği öne sürülmüştür (Doerfer 1965: 349-351). Benzer şekilde Eberhard da bokug sözcüğ̈̈nün Moğolca "sporcu (atlet), kahraman" anlamına gelen böke sözcüğü ile ilişkisini de sorgulamıştır. (Bazin 1994: 11).

İfade ettiği zengin anlamlarıyla bögü/bügü sözcügünün önemli şahısların erdemli vasıflarını belirtmek üzere Türk tarihinin en eski kaynaklarında olduğu gibi İslâmiyet sonrası dönemde de Türk asker, boy beyi ve hükümdar unvanlarında görmekteyiz (Donuk 1988: 10-11). A. Donuk, bu sözcügüun bügü/bükü/bögi gibi farklı hallerinden de bahsetmekte; ancak buku (p'u-ku) sözcüğünü bunlardan ayırarak ilk olarak $\mathrm{P}^{\prime} \mathrm{u}-\mathrm{ku}$ adlı Türk boyu ile ilişkilendirmekte; ayrıca bunun özel kişi adı ve unvan olarak kullanıldığını ve "şef, kumandan" anlamına geldiğini ifade etmiştir.

Kutadgu Bilig'de ise bögü sözcüğü "hürmet sanı" olarak yetmis,ten fazla yerde görülmektedir (Arat 1979: 119). 5 Bu ifadenin yorumu için ayrıca bkz. Mübahat Türker-Küyel, “Kutadgu Bilig'de Aile Kavramı”, Bilge, Ocak 1995,
Kış, S.3, s. 10. 


\section{Bögü/Bügü Sözcügüünün Kökeni ve Anlamı Hakkında Son Görüşler}

Geçmişte bögü/bügü sözcüğü ile türevlerinin anlam ve kökenlerinin dini bağlamda kullanımı hakkında bazı görüşler ortaya atılmıştır. Bazin'e göre bokug sözcüğünün Osmanlıca Redhouse sözlüğünde ileri sürüldüğü gibi Slavca "Tanrı" anlamındaki bor sözcüğü ile ilgisi bulunmamaktadır (Bazin 1994: 5-6). Bu görüş, daha önce beg (bey) sözcüğünün İran dilinde "Tanrı" anlamındaki bag, baga sözcüklerinden alınmış olabileceğine dair yapılan tartışmaları hatırlatmaktadır (Donuk 1988: 5). O. Karatay da bey ve büyü sözcüklerinin aynı köke uzandığını savunmaktadır (Karatay 2015: 11). Clauson ise, sözkonusu sözcügüü Moğolca'ya "erkek şaman" anlamında bö'e/böge olarak geçtiğini belirtmiştir.

Son zamanlarda böğ ü sözcüğünün anlamının dini ve mistik bağlamda ele alınmasına dair yapılan çalışmalara baktığımızda; O. Karatay, hem büyü, hem de bilgelik ile ilgili anlamlarının altını çizmekle birlikte özellikle Moğolca anlamını ve Kıpçak Türklerinin baş-şaman için kullandıkları beki sözcüğünün bögü ile kökteş olduğunu öne sürerek bögü'nün büyücülük ve hekimlik gibi görevleri de üstlenen "din adamı" anlamına vurgu yapmıştır (Karatay 2015: 7-12). Bögü'nün büvi varyantını değerlendiren Weicuyi ise, Modern Uygur Türkçesinde farklı ağızlarda büvi, büvü, büve, bübü olarak ifade edilen sözcügün "kadın hoca", "kadın şaman" anlamına geldiğini belirtmiş; Farsça bibi ("hanım, sahibe") sözcüğünün de muhtemelen böve < bögü'den geldiğini ileri sürmüştür(Weicuyi 2007: 216-217). Araştırmacı Uygur Budist ve Maniheist metinlerinde sıkça kullanılan ve "kutsal, bilge, hakim" anlamlarını ifade eden bögü'den türetilmiş bazı sözcüklerin anlamını metin örnekleriyle önermiş̧ir: bögülüg "ferasetli", bögülenmek "önceden bilmek, tahmin etmek" gibi (Weicuyi 2007: 215).

Weicuyi'nin makalesinde bildirdiği diğer bir iddia ise, bögü'nün Türklerin şamanist inancından geldiği ve Eski Türklerde siyasi lider ve şaman ayn kişi olduğu için "tanrının bedenleşmiş hali olarak görülen" (Weicuyi 2007: 214) hükümdara kutsal ve tanrısal anlam içeren bögü unvanı verildiğidir. Bu görüşe istinaden Türklerde hükümdarın Tanrı ile özdeşleşmesi gibi bir inanış olmadığını altını çizerek vurgulamamız gerekmektedir. Eski Türk toplumunda Türk hükümdarın Gök Tanrı ve atalar ibadeti için düzenlenen törenlere başkanlık etmekle birlikte ruhlarla iletişim kuran ve kehanetlerde bulunan kamların işlevlerin üstlenmemiştir. Ancak eğer bögü Eski Türkçede özellikle kamlar için kullanılmış ise; kamların bu olağanüstü mistik güçlerle gerçekleştirdikleri işlevlerinin; $g_{-}>$y ses değişimi ile bügü -> büyü haline dönüşüp "büyü" ile ilişkilendirilebilmesi anlaşılır görünmektedir.

Bu bağlamda başka bir çalışmayı gerçekleştiren Kazak araştırmacılar T. Moldabay ve A. Azmuhanova, Türkçe metinler üzerinden yaptıkları incelemede boge (böge)/boke (böke)/bigu sözcüklerinin "dinin başı", "baş din adamı" anlamında kullanıldığını öne sürmüşlerdir (Moldabay,Azmuhanova 2015: 49). Ancak verdikleri örneklerden çıkardıkları anlamda Türk kültürü ile örtüşmeyen bazı yanlış yorumlarda bulunmuşlardır. Örneğin Tonyukuk Yazıtı 34. satırda yer alan Tonyukuk ve Bögü Kağan'ın birlikte savaşta oldukları ifadesinde Bögü Kağan'1 Türklerinin dininin en başında bulunan ve kendisinden kehanet beklenen din adamı olarak kabul etmişlerdir. Oysa eski Türk dininde ruhban sınıfı ve bu sınıfın başında lider bir din adamı olmadığı ve savaşa gitmediği gibi büyük dini törenleri hükümdarların yönettiğini biliyoruz. Bu nedenle Weicuyi'nin önerisine dayanarak (Weicuyi 2007: 213) buradaki "Bögü Kağan" ifadesinde bögü’nün kağanın adı değil, unvanı olduğu ve bunun "Kutsal Kağan" olarak tercüme edilmesi gerektiği daha akla yakın görünmektedir.

Moldabay ve Azmuhanova bahsettiğimiz çalışmalarında verdikleri içinde bögü geçen 
Türkçe metin örnekleri; sözcügün Çince metinlerde "din adamı" anlamında aynen korunmuş olması ve Moğol kroniklerindeki bogu/böö karşılıklarından yola çıkarak daha büyük bir iddia ortaya atmışlardır: Eski Türk Dini'nin eski adının Tengrizm (Rusça Tengrianstvo) değil, Bogu (dini) olması gerekir. Kanaatimizce bögü'nün kökeninin baga sözcüğünden kaynaklanmış olması iddiasının ötesine geçen bu tez, kaynaklarda Türk dini yerine bu sözcüğün kullanılmış olduğunu ispat edememiştir. Üstelik bogu'nun din adamı anlamında kullanıldığını söyleyen araştırmacılar, bu tezle birlikte Türklerin Tengri /Gök Tanrı dinine bir anlamda yeniden; adını "din adamı"nın adından alan ve günümüzde artık bir din olmadığına dair görüşün ağırlık kazandığı "şamanizm" yakıştırmasını yapmış olmaktadırlar.

\section{bögü/bügü Sözcüğünün Kökeni ve Kronolojik Gelişimi Hakkında Düşünceler}

Bögü/bügü sözcüğünün kökeni ve listelediğimiz çoklu kullanımları arasından asıl anlamının hangisi olduğu konusu halen açık değildir. Çin yıllıklarında da görüldüğü üzere kadim Türk kültüründe bir boy veya uruğun adını, onu kuran veya liderliğini yapan kişinin adından alma geleneği mevcuttur (Clauson 2002: 7). "Oğuz" örneğinde görüldüğü gibi boyu kuran atanın adının gelecek nesillerde kullanılarak yaşaması sağlanmıştır. Cüveynî’nin aktardığı Uygur Türeyiş Destanı'nda adı geçen Buku Kağan'ın Afrasiyab olduğu hakkındaki rivayette; efsanevi ataya menşe atfetmek suretiyle Uygurların geçmişini daha geriye götürme çabası sezilmektedir. Ayrıca Türk tarihinde Göktürk döneminden itibaren bir çok Bögü/Buku Kağan adına rastlanması bu ata adını yaşatma geleneğini akla getirmektedir.

Aynı şekilde özellikle devletin önemli mevkilerinde bulunan kişiler geldikleri boyun adını unvan olarak kullanmışlardır. Bunun en güzel örneği, Birinci Göktürk devletinin yıkılışından sonra Çin hâkimiyetini kabul eden Pu-ku boyundan gelen ve Bögü Kağan'ın kayınpederi olan Pu-ku Huai-en'dir (Baykuzu 2014). “Bögü" sözcügüüle benzeşen buku'nun Türk lehçelerinin bir çoğunda "geyik" anlamına gelmesi, Türk kültüründe bir boyun kutsal addedilen bir hayvan ongunu ile ilişkilendirilmesi ile paralellik arz etmektedir. Benzer bir durum hayvan adı alan alpler ve kahramanlar için de geçerlidir (Gabain 1979; Gül 2006). Eski Türkçede özel kişi adlarına ilişkin antroponimlerin dilbilim açısından araştırılması için örnek bir çalışma olan makalesinde Y. Memmedli, mevki olarak unvan bildiren sözcüklerden, o kişinin sahip olduğu erdemleri bildiren sözcüklerden, hayvan adlarından türeyen kişi adlarını gruplandırarak örnekler vermiştir (Memmedli 1994: 97-107). Bir etnonim belirten "Türk" sözcüğünün anlam ve kullanımlarını incelediğimizde hem bir kişiye (efsanevi Türk Ata), hem onun kurduğu millete bu ad verilirken; Türk adı başta kuvvetli ve töreli olmak üzere bir çok erdem içeren nitelikleri bildiren sıfat anlamı ile bu milletin karakterini de tanımlamıştır. Dolayısıyla Eski Türkçede bir sözcüğün aynı anda hem etnonim ve antroponim olması veya bu iki tip özel ad türünden birinin diğerinden türemesi olağan bir durumdur.

Böyle bir çözümlemeyi Oğuz sözcüğünün etimolojisini inceleyen F. Bayat da dile önermiştir. Öküz sözcüğünün Altayca *pökü/pökür'den geldiği ileri süren Ramstedt'in ve arkasından onun bu görüşüne katılan Pelliot ve Poppe'nin önerileri doğrultusunda Bayat, boğa/öküz sözcüğünün ilk şekli olan bökür -pökür ve kelime başında $b / p^{\prime}$ nin düşmesiyle ökür sözcüklerinin semantic ölçekte türemelerini aşağıdaki şekilde göstermiştir (Şekil 1): 


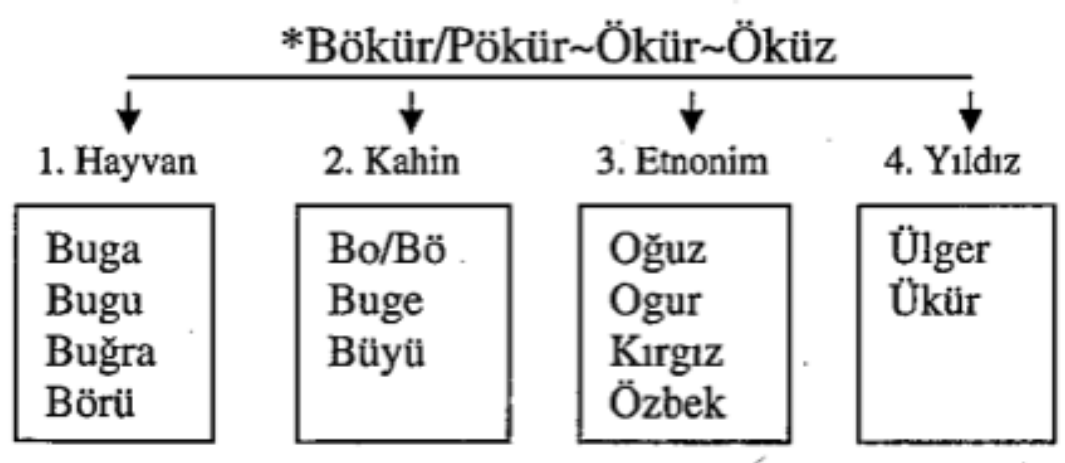

Şekil 1 F. Bayat tarafindan önerilen Ŏ̆uz sözcüğ̈̈ne ilişkin Semantik Türeme

(Bayat 2004:74)

Eğer bu çözümlemeyi temel alırsak bögü ve onunla ilişkilendirilen bokug sözcüklerinin boy, unvan ve erdemlilik anlamlarının her üçü de birbiriyle ilişkili ve aynı kökenden türedikleri mümkün gözükmektedir. Söz konusu sözcüklerin dilbilim anlaminda buku olarak hayvan adı ile de ilişkilendirilmesi, T. Gülensoy'un örneklerini verdiği üzere bö- kökünden türeyen hayvan adlarının çokluğuyla da örtüşmektedir (Gülensoy 2011: 171).

Bögü kelimesinin daha önce önerilmiş beg < baga değişiminde olduğu gibi baga kelimesinden türediği kesin değildir. Ancak baga sözcüğünün Göktürk döneminde bögü ile aynı anda diğer bir unvan niteleyici olarak kullanılıyor olması (Şirin User 2010: 272) da bu görüşüu çürütmez. Zira Eski Türkçede aynı nesneyi/kişiyi/kavramı niteleyen eşanlamlı bir çok kelime var olduğu gibi, diğer dillerden geçen sözcüklerin Türkçeleşmiş hallerinin yanı sıra yabancı sözcükler de korunmuştur. Bögü ve baga sözcükleri, Uygur döneminde de Bögü Kă̆an ve Tun Baga Tarkan özel kişi adlarında eş zamanlı olarak görülmektedir. Ancak bögü kelimesinin zaman zaman birlikte kullanıldığı bilge sıfatına kıyasla dini niteliği ve Tanrı'ya atfedilen veya onunla ilişkilendirilen "ilahı̂”, "kutsal" anlamları kanaatimizce ön plana çıkmaktadır. Bu tür kutsiyet belirten unvanların Eski Türk hükümdarları için her dönemde kullanıldıkları bilinmektedir. Ancak kronolojik gelişmeye baktığımızda; Gök Tanrı dini çerçevesinde din ve devlet açısından en yüksek mertebeyi temsil eden hükümdar kavramının sona ermesinden sonra bögü/bügü sözcüğünün büyü ve büyücü anlamını kazanması ve din adamları için kullanılması nasıl mümkün olmuştur?

Bunun bögü sözcüğüne ilişkin bir anlam daralması olabileceğini destekleyen bir unsur, G. Mensching'in "ilkel karizmatik krallıkta fonksiyonların birliğinin bozulması" teorisidir (Mensching 2012, 57-63). Bu teoriye göre arkaik devirde gücünü (karizmasını) Tanrı'dan alan kral, kutsal ve kutsal dışı olarak adlandırılan, din ve devlet işlerini birlikte icra etmekteydi. Mensching bu sebeple din ve devlet işlerini birlikte yürüten kralın, başta bütün bu fonksiyonları birlikte yürütmesine sebep olan kraliyet fonksiyonu olmak üzere rahip veya sihirbaz durumunda olduğu dini fonksiyonu, hukuki fonksiyonu ve ordu komutanı olarak görev yaptığı askeri fonksiyonundan bahsetmektedir. Karizmatik krallı̆̆ın laikleşmesi ile birlikte krala ait fonksiyonların original birliği zamanla bölünmüş; kralın yanında rahip, büyücü ve bağımsız hakimler kendilerini göstererek kralın elinde artık "kutsal dışı" olarak tanımlanan yönetim ve ordu komutanlığı kalmıştır.

Mensching'in teorisini göz önüne aldığımızda bögü sözcüğü, Türk hükümdarı için dini 
fonksiyonun ortadan kalktığı dönemden sonra onun sadece eski dini fonksiyonunu icra etmekle yükümlü olan din adamlarına ithaf edilerek anlam daralmasına uğramış olabilir. Türklerin yabancı dinleri kabulü ile birlikte, özellikle Maniheizm döneminde ruhban sınıfının ortaya çıktığını ve idare anlamında din ve devlet işlerinin birbirinden ayrıldığını söylemek mümkündür. Ancak bu ayrım ile birlikte hükümdarın karizmasını ve ilahi vasıflarını yitirdiğini söylemek mümkün değildir. Zira Uygur hükümdarları, Maniheizm'e girdikten sonra da "Tengri, kün ve ay" gibi kutsal adledilen ilahi unsurlardan kut almaya devam etmişler ve üstelik Mani dininin hamisi olarak zahag-ı Mani "Mani' nin tecellisi, oğlu anlamında zahag-i Mani (Müller 1910: 95) gibi unvanlar alarak kutsiyetlerini devam ettirmişlerdir. Hatta Maniheizm'i kabul eden Bögü Kağan'ın aynı zamanda “Tengri Kağan” adını kullanması, bu unvanların aynı dönemde eş anlamlı olarak kullanılma ihtimalini düşündürmektedir.

Bu konuda akla gelen daha zayıf bir diğer teori, belki de arkaik haliyle kutsal bir hayvan, boy, unvan veya din adamın ifade eden Eski Türkçe bögü sözcüğünün özellikle Maniheizm başta olmak üzere yabancı dinlerin etkisiyle Farsça baga sözcüğünü de içeren "ilahilik" vasfını ifade etmek üzere değişikliğe; bir nevi "anlam genişlemesi" ne uğramış olmasıdır. Buna göre yabancı dinin etkisinin zayıflaması ve kalkması ile de bu anlam genişlemesi ortadan kalkıp sözcük nihayet "kutsal güce sahip din adamı" şeklindeki Türkçe eski kullanımını kazanmış olabilir. Her iki teori de şimdilik güçlü delillerle desteklenmekten uzaktır.

\section{Sonuç}

bögü/bügü ve bokuk/bokug/bukuk/bukug sözcükleri Eski Türk kültüründe; kökeni Tölesler'e uzanan bir boy adı, ilahi ve kutsal anlamı nedeniyle başta akla dayalı olmak üzere bir çok farklı erdemi ifade edebilen bir sıfat, bu sıfatlar sebebiyle hükümdar, askeri komutan, lider için kullanılan ad veya unvan ve din adamı adı olarak kullanılmışlardır. Son dönemde yapılan araştırmalarda bögü sözcügüun Eski Türkler tarafından hükümdar ve askeri unvan olarak kullanımından ziyade din bağlamındaki kullanımı ve anlamı üzerinde durulmuştur. Bunun sebeplerinden biri, günümüzde halen farklı Türk lehçelerinde ve Moğolcada bu sözcüğün "erkek veya kadın din adamı" için kullanılıyor olmasıdır.

Eski Türk kültüründe boylar, hükümdarlar, komutanlar, alpler ile boyu simgeleyen kutsal hayvanlara ait ad veya unvanların birbirleriyle geçişli olarak kullanılması sebebiyle bögü sözcügün kullanıldığı bağlamların çizgisel bir kronolojisini çıkarmak oldukça zor görünmektedir. Bu karmaşık durumun Maniheizm ve Budizm gibi yabancı dinlerle nasıl şekillenmiş olduğu da, daha geniş ölçekte incelenmesi gereken oldukça mühim ve ilginç bir sorudur.

Ayrıca bögü sözcügüunün Tanr/Tengri veya ilahi anlamına gelen Farsça baga sözcüğü ile ilişkisi halen aydınlatılmayı beklemektedir. Sezgisel bir yaklaşım ile sözcüğün din bağlamında kullanılan "kutsal, ilahi" anlamının baskın ve belki "ilk ve asıl anlam" olduğu öne sürülebilirse de henüz kanıtlanmaktan uzaktır. Belki de zaman içinde yaşanan anlam daralması sonucunda bögü sözcüğün hangi kişi için kullanıldığına bağlı olarak bu kutsallık; bilgelik, fiziki güç veya ruhani güç anlamı ile sınırlandırılmış olabilir.

Diğer bir konu bögü ve bokuk arasındaki ilişkinin dilbilim ve semantik açıdan mahiyetidir. $\mathrm{Bu}$ iki sözcügün Göktürk döneminden itibaren eşzamanlı kullanımı, birinin diğerinden türetildiği veya ayn kökten geldiği teorilerini çürütmemekle birlikte; eşanlamlı olmaktan ziyade farklı anlam/nesne/kişi veya topluluklara işaret ediyor olabileceğini düşündürmektedir. Örneklerini verdiğimiz Eski Türkçe metinlere göre; bokuk/bokug sözcüğü 
daha çok etnonim ve antroponim olarak özel bir boy/kişiyi tanımlamakta kullanılmıştır. H. Şirin'in bahsettiği etnik mensubiyeti bilinmeyen bukug tutuk örneğinde, belki bukug adı, boy niteleyen bir unvan olarak kullanılmıştır. Hiç şüphesiz Hun döneminden Turfan Uygurlarına kadar rastladığımız bokug/bokuk sözcügüünün Tölesler arasında yer alan tek bir boy için kullanılmış olması ihtimali heyecan vericidir. Ayrıca örneklerini vermeye çalıştığımız Buku Kağan'ın destanlarda Afrasiyab olarak kabulü veya etimolojik olarak önerilen Bökür-Oğuz ile bağlantısı da antroponim olarak daha fazla incelenmeyi hak etmektedir.

Sonuç olarak, bögü/bügü sözcüğünün Eski Türkçe Budist metinlerin tercümeler vasitasıyla ortaya çıktığı dönemde (en erken geç IX.-X. yüzyıllar) Sanksritçe prajñā sözcüğünün karşılığı olarak; akıl vasıtasıyla ulaşılan bilgeliği ifade eden "hikmet" erdeminin de ötesinde, gerektiğinde Zen Budizmi'nde olduğu gibi anlık bir aydınlanma ile kazanilabilecek mistik, ilahi veya ruhani sezgi ve kavrayışı ifade eden "irfan" kelimesini de içeren anlama sahip olması bize kelimenin geç kullanımlarının (büyü, din adamı) mistik kaynağı hakkında ipucu vermektedir. Ancak bögü/bügü kelimesinin Eski Türkçenin daha önceki dönemlerinde tam olarak hangi anlamda kullanıldığını veya yukarıda bahsettiğimiz "baga" ile muhtemel ilişkisinde olduğu gibi başka dillerden, başka dinler vasıtasıyla ödünçlenmiş bir sözcük olup olmadığını tespit etmek için elimizde yeterli delil bulunmamaktadır.

Çalışmamızda bazı örneklerini vermeye çalıştığımız bögü/bügü sözcüğünden yapım ekleriyle türemiş fiil ve isimleri hakkında da Türk dili uzmanları genellikle benzer düşünceler ileri sürmüşlerse de bögü/bügü kelimeleri için farklı köklerden bahsedilmiş olması, daha fazla etimolojik araştırmayı elzem kılmaktadır. Hatta bögü/bügü kelimesindeki ses değişiminin nasıl ve ne zaman olduğu veya aynı anda kullanımı konusu da açık değildir. Tüm bu nedenlerden ötürü, sözkonusu sözcük ve türevlerine ilişkin derli toplu bir kök ve anlam bilgisine ulaşmayı amaçladığımız makalemizde daha ziyade sistemli bir şekilde, yeni bulgular ve metodlar ışığında, özellikle etnonim ve antroponimlerden dolayı tarih disiplininin de yardımıla yeniden işlenmesi gereken bir çok malzeme ile karşılaştık. Makalemizde bu malzemeyi sunmanın yanı sıra sözcüğün geçirmiş olabileceği evreler hakkında bazı teoriler öne sürüp yorumlamaya çalıştık. Muhtemel anlam genişlemesi, daralması gibi yorumlarımıza özellikle bu konuya yeni bir perspektif getirmek ve yeni tartışmalara yol açmak açısından yer vermeye çalıştık. Ancak bu makalede incelenen sözcüklerin kullanımları, anlamları ve özellikle kökenlerine ilişkin cevaplardan çok sorulara sahip olduğumuzu söylememiz gerekir. Bulunan yeni yazıtlar, okunan yeni metinler ve yeni yaklaşımlar ile beraber Eski Türkçe yazıt ve metin külliyatı üzerinde yapılacak detaylı bir kronolojik analiz çalışmasının, bize bu soruları cevaplamamıza yardım etmesini temenni ediyoruz.

\section{Summary}

Different opinions have been put forward so far on the root, meaning and etymology of the Old Turkic bögü/bügü word that came out as a personal name or title. bögü/bügü has also been associated earlier with the word bokuk/bokug/bukuk/bukug used in Hun, Gokturk and Uyghur periods. This view has been almost refuted by the fact that these words were written in different way in Old Uygur script and in Chinese transcriptions. About bögü/bügü, encountered in Chinese sources, Turkic inscriptions, Uygur Buddhist and Manichaean texts, Uygur epics and Kutadgu Bilig, several linguists emphasized its meanings as "wise, sage, savant, sacred, physician, magician". 
In our paper we first examined the usage of these words within some important texts in the light of past studies. During Huns period, in a Turkic verse from $4^{\text {th }}$ century written in Chin Shu translated by L. Bazin, bokug/bukuk was used as a commander title. Bazin gave also some other examples in texts from different periods for the usage of this word and its derivatives as tribe or animal names. In Turks period, bögü/bög<ü> was used as ruler's title in Tonyukuk Inscription and bukug as another title describing a governor (tutuk) in Bilge Kagan Inscription. In Orhun and Turfan periods, Bögü ve Bokug/Bukuk/Bokuk was especially used a title in personal names, as seen in Bögü Kă̆an and other Uygur rulers. In the famous Uygur epic narratating the emergence of Uygur tribe (Türeyiş Destani), one of the five children born from trees was called Boguk Han according to Chinese sources and Boku/Buku Tegin by Cüveynî. Bukug was also recorded as a title in Taryat Inscription. The usage of bokug or bokuk (having meaning as "bird's crow, knob, tuber") as a tribe name by Uygurs was especially highlighted by L. Clark who published Uygur Manichaean texts in Berlin turfan Collection. Another example from bilingual (Uygur and Chinese) Turfan İdikuts' Inscription dated from approx.. 14 $14^{\text {th }}$ century, found in Kansu Region and read by G. Shimin and J. Hamilton is the expression bokuk tözlüg pundarik çeçek, translated by the same authors as "lotus flower of bokuk "log or race -having double meanings-". The third type of usage of bögü/bügü by Uygurs was as the descriptor of personal characteristics expressing "virtue". This word was used in Old Uygur Buddhist texts as the Uygur translation of Sanskrit prajña term expressing "wisdom". Prajñā refers not only wisdom virtue attained by mind, but also knowledge obtained by insight, cognition and intution (irfan). The six virtues (Skr. päramitā) needed to be attained by boddhisattvas wishing to become Buddhas, was called as altı paramıt / altı törlüg bügülenmek Erdem, bügülenmek explained by M Erdal and K. Eraslan "having mystical wisdom or being supernatural", probably leading to later "magic/magician" meanings of bögü/bügü. In Uygur texts, bögü/bügü was also used as synonym of "right" (right thought, right behavior...) The possible later derivation of this word as "böke", meaning "strong" could be another aspect of bögü/bügü expressing virtue in general.

Regarding the origin of bögü/bügü and its derivatives, it was previously proposed that the religious context was relevant due to the relations with bag, baga (Persian) and bor (Slavian) words meaning "God", but not much supported with strong arguments. In our paper, we introduced some of the ideas that have recently emerged, emphasizing the meaning of bögü/bügü as religious person, used in Mongolian as male shaman according to Clauson. One of the two proposals to be noted belongs to O. Karatay who pointed thet beki, used for head of shamans by Kipchak Turks, came from the same origin as bögü, the religious man played role both as magician and physician. The second study by Kazak scholars T. Moldabay ve A. Azmuhanova noted that boge (böge)/boke (böke)/bigu words referred to "head of religion" or "religious leader" and argued that the name of old religion of Turks was Bogu and not Tengrism, which was criticized by us due to weak argumentation.

In the second section of our paper, we tried to reveal the main and the original meaning of the word. Turks have an ancient etnonym tradition where the personal name of tribe leader was given to his tribe name. Conversely, the leading persons of state got their title from their tribe name. Other old Turkish traditions are; 1 ) the fact that each tribe has its own ongon ,2) the antroponym in which some warriors and heros got the name of animals, indicated by $\mathrm{Y}$. Memmedli. The second shows a parallelism with the relation of bögü and buku, meaning "deer" in many Turkish dialects. So, in Old Turkic, it seems very probable that a word is both an antroponym and an etnonym or one is derived from the other of these special naming form.

As bögü has a meaning as "divine, sacred" which is especially used as title Turkish 
ruler having these two virtues, we tried to follow up the chronological link between this meaning and the later meaning as magician or religious man, in order to understand the semantical change. Our first proposal was "semantic restriction" based on G. Mensching theory of "the breakdown of functional association in primordial charismatical kingship", where king has lost his religious leader function upon secularization. This theory fits also with Turkish ruler, who leaded the religious ceremonies held for Sky God, ancestors and land-water spirits. Our second proposal, which seems less probable, is based on the theory of "semantic extension" where the most archaical meaning of bögü was "sacred animal, tribe or religious man" meaning which ended up with most vast "divine" meaning by the introduction of a foreign religion like Manichaeism, with the reflection of Persian baga word. It could be resulted that the original meaning came up when foreign religion impact was forgotten. As a conclusion, we hope that our study will stimulate further research on the etimology and semantical aspects of this important old Turkic word by the systematical and chronological study of recently discovered inscriptions and texts and new approaches. 


\section{Kaynakça}

ALYILMAZ, Cengiz (2003), “Bugut Yazıtı ve Anıt Mezar Külliyesi Üzerine”, Selçuk Üniversitesi Türkiyat Araştırmaları Dergisi (13), 11-21.

ARAT, Reşid Rahmeti (2007), Eski Türk Şiiri, 4. Baskı, Ankara: Türk Tarih Kurumu Basımevi.

ARAT, Reşid Rahmeti (1979), Kutadgu Bilig III Indeks, Haz. Kemal Eraslan vd., Türk Kültürünü Araştırma Enstitüsü, İstanbul: Edebiyat Fakültesi Basımevi.

ATA, Aysu (2008), 100. Doğum Yıldönümüne Armă̆an Prof. Dr. Saadet Çă̆atay'ın Yayınlanmış Tüm Makaleleri C. 1, İstanbul: Ayaz Tahir Türkistan İdil-Ural Vakfı Yayınları .

AYDIN, Erhan (2011), "Yenisey Yazıtlarında Geçen Unvan ve Unvan Niteleyicileri”, TDAYBelleten (2011-2), 5-26.

BANG, Willi; GABAIN, Annemarie von (1929), "Türkische Turfan Texte II", Sonderausgabe aus den Sitzungsberichten der Preussischen Akademie der Wissenschaften, Phil.-hist. Klasse, Berlin, 1929, 411-430 + VI Tafeln.

BANG, Willi; GABAIN, Annemarie von (1931), Analytischer Index Zu den Fünf Ersten Stücken der Türkischen Turfan-Texte, Berlin: Verlag Der Akademie der Wissenschaften in Kommission bei Walter de Gruyter U. Co.

BAYAT, Fuzuli (2004), “Uz Ğuz Oğuz Kavim Adının Etimolojisi”, Karadeniz Araştırmaları (3), 71- 77.

BAYKUZU, Tilla Deniz (2014), “T'ang Hanedanlığının Büyük Türk Generali Pu-ku Huai-en”, Ankara Üniversitesi Dil ve Tarih-Coğrafya Fakültesi Dergisi (54/1), 377-400.

BAZIN, Louis (1994), Les Turcs Des Mots, Des Hommes (Haz. Michèle Nicolas, Gilles Veinstein), Budapest: Akadémiai Kiadó.

CAFEROĞLU, Ahmet, Eski Uygur Türkçesi Sözlüğü, 3. Baskı, İstanbul: Enderun Kitabevi.

CHAVANNES Édouard, PELLIOT, Paul (1911), “Un Traité manichéen retrouvé en Chine ”, Journal Asiatique, 10ème série:18, 499-617.

CLARK, Larry (2009), "Manichaeism Among the Uyghurs: The Uyghur Khan of the Bokug Clan", New Light on Manichaeism : Papers from the Sixth International Congress on Manichaeism (Ed. J. D. BeDuhn), Leiden-Boston: Brill, 61-71.

CLAUSON, Gerard (2002), Studies in Turkic and Mongolic Linguistics, $2^{\text {nd }}$ Edition, London: Routledge.

CLAUSON, Sir Gerard (1972), An Etymological Dictionary of Pre-Thirteenth Century Turkish, Oxford : Clarendon Press.

DOERFER, Gerard (1965), Türkische und Mongolische Elemente im Neupersischen, Band II. Türkische Elemente im Neupersischen alif bis ta, Wiesbaden: Franz Steiner Verlag GmBH.

DONUK, Abdülkadir (1988), Eski Türk Devletlerinde Îdari-Askerî Unvan ve Terimler, İstanbul: Türk Dünyası Araştırmaları Vakfı.

ERASLAN, Kemal (2012), Eski Uygur Türkçesi Grameri, Ankara: Türk Dil Kurumu Yayınları.

ERDAL, Marcel (1991), Old Turkic Word Formation. A Functional Approach to Lexicon, C. II, Wiesbaden: Otto Harrassowitz.

GABAIN, Annemarie von (1979), “Die Staatlische Verfassung Des Uigurischen Königreichs von Koço, 9.-13. Jh. n. Chr.", XVI. Milletlerarası Altaistik Kongresi (21-21.X.1973 Ankara) Bildirileri, Ankara: Türk Kültürünü Araştırma Enstitüsü Yayınları, 153-164.

GABAIN, Annemarie von (2007), Eski Türkçenin Grameri, 5. Baskı, Çev. Mehmet Akalın, Ankara: Türk Dil Kurumu Yayınları.

GÜL, Bülent (2006), “Hayvan Adları ile Kurulan Türk ve Moğol Kişi Adları”, Türkbilig (12), 185191.

GÜLENSOY, Tuncer (2011), Türkiye Türkçesindeki Türkçe Sözcüklerin Köken Bilgisi Sözlüğ̈̈ A-N, 2. Baskı, Ankara: Türk Dil Kurumu Yayınları

HAMILTON, James (1986), Manuscripts ouighours du IXe-Xe Siècle de Touen-houang, 2 cilt, Paris: Peeters.

KARATAY, Osman (2015), “Hem Büyücü, Hem Rahip, Hem de Tabip: Uzlaşma Neden Yok?”, Türk Dünyasi Incelemeleri Dergisi (15/1), 7-12.

KAŞGARLI MAHMUD (1941), Divanü Lugat-it Türk Tercemesi, C. III, Çev. Besim Atalay, Ankara: Türk Dil Kurumu Yayınları. 
KLIMKEIT, Hans Joachim (1993), Gnosis on the Silk Road: Gnostic texts from Central Asia, San Fransisco: HarperSanFrancisco.

LE COQ, Albert von (1913), Chotscho. Ergebnisse der kgl. Preussischen Turfan Expeditionen, Berlin: Walter de Gruyter.

LE COQ, Albert von (1912), “Ein manichaisches Buch-Fragment aus Chotscho", Festschrift Vilhelm Thomsen, Leipzig, 145-154.

MEMMEDLİ, Yunus (1994), “Eski Türkçede Şahıs Adları ve Unvanları”, TDAY-Belleten, 95-110.

MENSCHING, Gustav Mensching (2012), Din Sosyolojisi, (Çev. Mehmet Aydın), 3. Baskı, Konya: Litera-Türk Yayınları.

MOLDABAY, Talgat, AZMUHANOVA, Ayman (2015), “Religion of Old Turks”, Anthropologist 21 $(1,2), 46-50$.

MÜLLER, F.W.K. (1911), Uigurica II, AKPAW, Berlin: Verlag der Königlichen Akademie der Wissenschaften.

ROUX, Jean-Paul (2015), Eski Türk Mitolojisi, (Çev. Musa Yaşar Sağlam), 2. Baskı, Ankara: BilgeSu Yayınları.

SERTKAYA, Osman (1995), Göktürk Tarihinin Meseleleri/Probleme der köktürkischen Geschichtel Some Problems of Köktürk History, Türk Kültürünü Araştırma Enstitüsü Yayınları: 131, Ankara: Ankara Üniversitesi Basımevi.

SHIMIN, Geng, HAMILTON, James (1981), “L'inscription ouïgoure de la stèle commémorative des Iduq qut de Qoco", Turcica (13), 10-54.

ŞEN, Serkan (2002), Eski Uygur Türkçesinde İkilemeler, Samsun 2002: Ondokuz Mayıs Üniversitesi Sosyal Bilimler Enstitüsü (Yayınlanmamış Yüksek Lisans Tezi).

ŞEN, Serkan (2015), Eski Uygur Türkçesi Dersleri, İstanbul: Kesit Yayınları.

ŞİRIN USER, Hatice (2010), Köktürk ve Ötüken Uygur Uygur Kağanlı̆̆ı Yazıtları \& Söz Varlığı Incelemesi, 2. Baskı, Konya: Kömen Yayınları.

THIERRY, François (1998), “Les Monnaies de Boquq Kaghan des Ouighours (795-808)”, Turcica (30), 263- 278.

TOKYÜREK, Hacer (2011), Eski Uygur Türkçesinde Budizm ve Maniheizm Terimleri, Kayseri: Erciyes Üniversitesi Sosyal Bilimler Enstitüsü, (Yayınlanmamış Doktora Tezi).

WEICUYI (2007), “Uygurcadaki “büvi” Kelimesinin Kökeni Üzerine”, (Çev. Alimcan İNAYET), Türk Dünyası Incelemeleri Dergisi / Journal of Turkish World Studies (C. VII/2), 213-217.

YILMAZ, Hüseyin (2007), Budist Metafiziği, Ankara: Hece Yayınları. 